\title{
Mangrove ecosystem in North Sumatran (Indonesia) forests serves as a suitable habitat for mud crabs (Scylla serrata and S. olivacea)
}

\author{
RIKA KARNIATI ${ }^{1}$, NURDIN SULISTIYONO ${ }^{1,2}$, RIZKA AMELIA ${ }^{1}$, BEJO SLAMET ${ }^{1,2}$, YUNTHA BIMANTARA $^{1}$, \\ MOHAMMAD BASYUNI ${ }^{1,2 v}$ \\ ${ }^{1}$ Department of Forestry, Faculty of Forestry, University of Sumatera Utara. Jl. Tri Dharma Ujung No. 1 Kampus USU Medan, Medan 20155, North \\ Sumatra, Indonesia. Tel./fax.: +62-61-8201920, ^email: m.basyuni@usu.ac.id \\ ${ }^{2}$ Center of Excellence for Mangrove, University of Sumatera Utara. Medan 20155, North Sumatra, Indonesia
}

Manuscript received: 16 January 2021. Revision accepted: 25 February 2021.

\begin{abstract}
Karniati R, Sulistiyono N, Amelia R, Slamet B, Bimantara Y, Basyuni M. 2021. Mangrove ecosystem in North Sumatran (Indonesia) forests serves as a suitable habitat for mud crabs (Scylla serrata and S. olivacea). Biodiversitas 22: 1489-1496. Mud crabs (Scylla serrata and Scylla olivacea) are often found in muddy substrates associated with mangrove vegetation. The habitat of these crabs ranges from tropical estuaries to sheltered subtropical areas, riverbanks, lower river traits, and intertidal areas. These crabs have an important economic value, and it increases the income of the communities living around the mangrove area. This study aims to obtain more information on the environmental factors of habitat for mud crabs (S. serrata and S. olivacea): insights on the effects of abiotic and biotic factors and potential economic value, in the village of Lubuk Kertang, Langkat, North Sumatra, Indonesia. Data were collected by measuring abiotic factors (temperature, $\mathrm{pH}$, salinity, dissolved oxygen, mud depth, distance from the river) and biotic factors (mangrove stand density through canopy cover). The dataset was analyzed using a binary logistic regression analysis with a stepwise method. Results showed that the abiotic factors that contributed to the presence of the mud crab were dissolved oxygen and a mud depth of $68.7 \%$. Meanwhile, the remaining 31.3\% that contributed to the presence of mud crabs were abiotic factors (temperature, $\mathrm{pH}$, salinity, distance from rivers) and biotic factors (stand density through canopy cover). The present study suggests that dissolved oxygen and mud depth have an important function in predicting the presence of mud crabs.
\end{abstract}

Keywords: Abiotic and biotic factors, crab density, dissolved oxygen, mangrove forest, mud depth

\section{INTRODUCTION}

Mangroves are well-known in tropical and subtropical zones. They support a wide range of ecosystem services that provide spawning habitat and a food supply for many marine animals, including fish, shrimp, uca-uca crabs, rock crabs, and mud crabs (Wilson 1989; Lee 1998; Murdiyarso et al. 2015; Basyuni et al. 2018; Fitri et al. 2018; Salim et al. 2018; Fawwaz et al. 2019). Mud crabs generally inhabit muddy estuaries and embankments in mangrove ecosystems affected by tidal waves of seawater (Bir et al. 2020; Quinitio 2017). Therefore, environmental changes may affect the carrying capacity of the habitat and deplete the mud crab population (Indarjo et al. 2020).

Mud crabs are a very important fishery resource for local communities with commercial value in the form of demand and prices in the international market, as well as a fairly high growth rate of health. Mud crabs of Scylla serrata, $S$. paramamosain, $S$. olivacea, and $S$. tranquebarica are especially popular throughout the tropical and subtropical zones of the Pacific and Indian Ocean (Glaser and Diele 2004; Dan and Hamasaki 2014; Mirera and Mos 2014). This Scylla species of mud crab is in great demand as a quality food ingredient because of its size, nutritional content, and softness (Azra and
Ikhwanuddin 2016). In addition, the sarasin contained in mud crabs is used as a therapeutic or prophylactic agent for disease control and health management (Anju et al. 2019).

The need for mud crabs arises from catches in nature, the frequency/amount of which mostly fluctuates. According to Tetelepta et al. (2020), the high demand for mud crab, both in the village of Lubuk Kertang and elsewhere, has a significant impact on the natural population of mud crabs. It has been reported that molting mud crab has been developed in Lubuk Kertang as a mangrove ecosystem service (Basyuni et al. 2020). Mud crabs were also cultivated for many years in Asia, mainly based on the capture and fattening of juveniles from the wild, particularly in Southeast Asia where production is rapidly increasing (Petersen et al. 2013; Hungria et al. 2017). Given the importance of mud crabs, this study was aimed to obtain further insight into the factors influencing the presence of mud crabs (S. serrata and S. olivacea), as well as their potential economic value in the village of Lubuk Kertang, Langkat, North Sumatra, Indonesia. Thus, it is expected that the results of this study can provide considerable information about the factors affecting growth as well as the potential economic value that can be used as a reference in the cultivation of mud crabs. 


\section{MATERIALS AND METHODS}

\section{Study area}

The study was carried out in the mangrove forest of Lubuk Kertang Village, Brandan Barat Sub-district, Langkat District, North Sumatra Province, Indonesia, which has an area of around 1200 ha. The village of Lubuk Kertang is situated at $04^{\circ} 02^{\prime} 34.25^{\prime \prime}-04^{\circ} 05^{\prime} 27.11^{\prime \prime} \mathrm{N}$, and between $98^{\circ} 14^{\prime} 57.92^{\prime \prime}-98^{\circ} 18^{\prime} 37.87^{\prime \prime}$ E. In the restored mangroves, the sampling locations were conducted to collect mud crabs as shown in Figure 1.

The investigated mangrove forest was found by seven families and 16 species: from the Rhizophoraceae family: Rhizophora apiculata, $R$. mucronata, Bruguiera gymnorrhiza, B. sexangula, and Ceriops tagal; from the Acanthaceae family: Avicennia marina, A. lanata, A. officinalis, and Acanthus ilicifolius; Combretaceae consisted of Lumnitzera racemosa and L. littorea. Moreover, Excoecaria agallocha (Euphorbiaceae), Scyphiphora hydrophyllacea (Rubiaceae), Sonneratia caseolaris, and S. alba (Sonneratiaceae) and Xylocarpus granatum (Meliaceae) were detected. It was crossed by the Lubuk Kertang and Tanjung Balai rivers.

\section{Data collection and analysis}

Data were collected in May-June 2018 with a purposive sampling method by making a plot measuring $5 \times 5 \mathrm{~m}(25$ $\mathrm{m}^{2}$ ) in the mangrove area and as many as 71 plots (Figure 1). In each plot, abiotic factors (water temperature, $\mathrm{pH}$, salinity, dissolved oxygen, depth of mud, distance of river plot points, and number of potential burrows presented on the tally sheet) and biotic factors (canopy cover) were measured to determine the density of crabs recorded with the number of crabs found through the crab traps installed in each plot. Observations for abiotic factors were carried out in the morning at low tide and when the sea waves were receding according to Ulfa (2017). Data collection on mangrove vegetation density was carried out on each measurement plot using the canopy cover application in JPG format.

\section{Multicollinearity test and regression analysis}

The multicollinearity test aims to determine whether there is a relationship among the independent variables, namely temperature, $\mathrm{pH}$, salinity, dissolved oxygen, mud depth, rivers, and canopy cover (Yoo et al. 2014). In a good regression model, there should be no correlation among the independent variables.

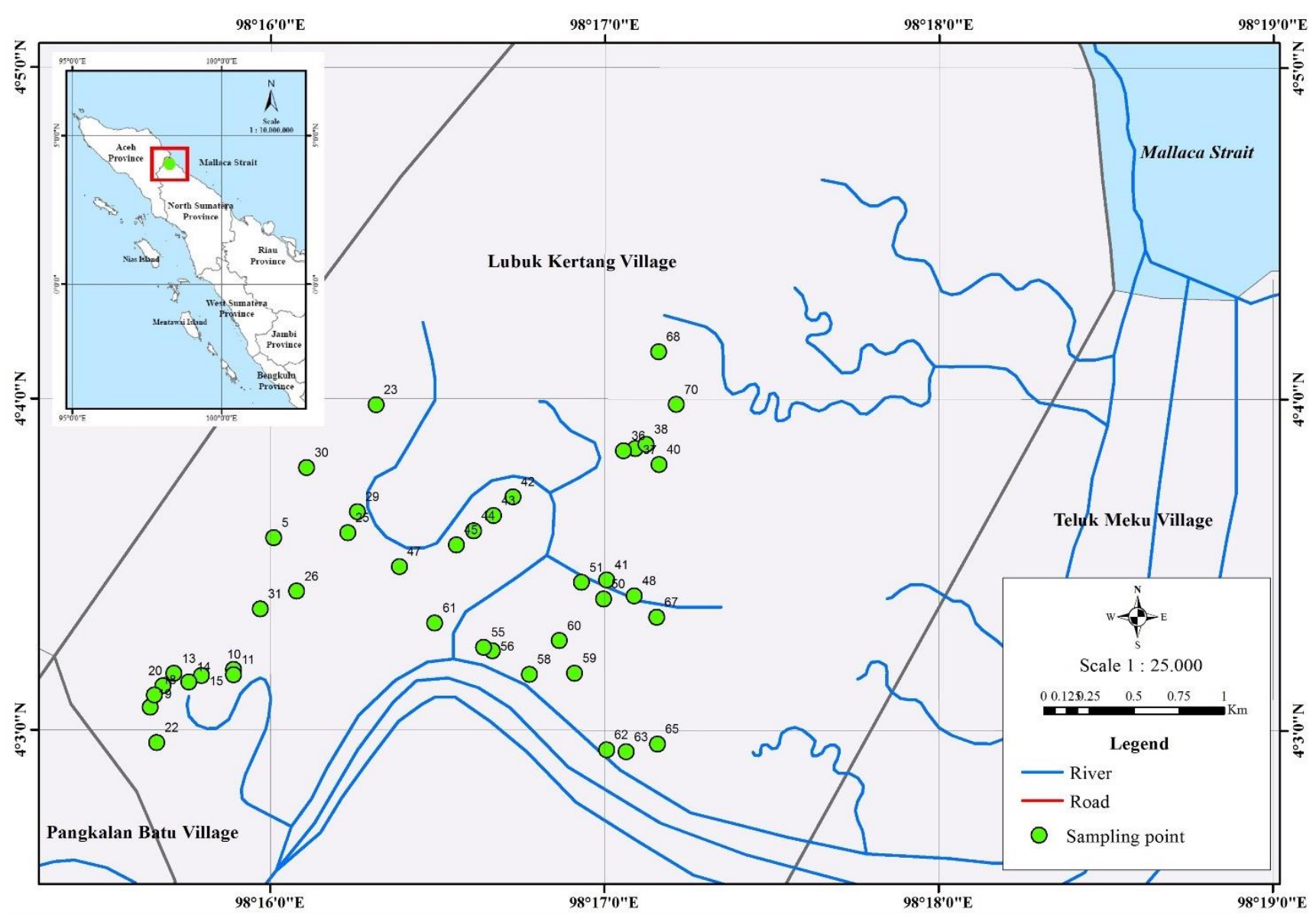

Figure 1. Sampling area showing the mangrove forest located near Lubuk Kertang village, Brandan Barat Sub-district, Langkat District, North Sumatra, Indonesia 
A binary stepwise logistic regression analysis (Archer et al. 2007) was performed to determine the factors influencing the presence of mangrove crabs. The factors acting as independent variables are dissolved oxygen, sludge depth, salinity, $\mathrm{pH}$, temperature, and canopy cover, while the dependent variable is the presence or absence of mud crabs. The analysis used in this research is binary logistic regression analysis using the stepwise method. In general, the binary logistic regression equation can be formulated by Archer et al. (2007) as follows:

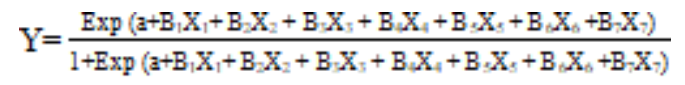

Where: Y: dependent variable (0: mangrove crab not existing; 1: mangrove crab existing); Exp: 2,72; a: constant; $\mathrm{B}$ : coeficient; $\mathrm{X}$ : independent variable $\left(\mathrm{X}_{1}\right.$ : temperature $\left({ }^{\circ} \mathrm{C}\right) ; \mathrm{X}_{2}: \mathrm{pH} ; \mathrm{X}_{3}$ : salinity $(\%) ; \mathrm{X}_{4}$ : dissolved oxygen $(\mathrm{mg} / \mathrm{L}) ; \mathrm{X}_{5}$ : mud depth $(\mathrm{cm}) ; \mathrm{X}_{6}$ : river $(\mathrm{m}) ; \mathrm{X}_{7}$ : canopy cover $(\%)$.

\section{Model validation}

The results of the probability of mud crab existence were compiled based on a binary logistic regression model using the method of Hosmer et al. (2013), where p > 0.05 was accepted at $\mathrm{H}_{0}$. The logistic regression model was able to explain the data and there was no difference between the model and its observation value. This shows that the logistic regression equation can be used to explain the relationship between the independent and the dependent variable. Meanwhile, for $\mathrm{p}<0.05$ to be rejected at $\mathrm{H}_{0}$, the logistic regression model must be unable to explain the data and there would be a difference between the model and its observation value.

On the other hand, model validation testing was conducted using the Wilcoxon statistical test by looking at the Z-value and the p-value (Asymp. Sig. 2-tailed). Model validation was performed to determine the accuracy of the presence of mud crab. The Z-value and p-value (Asymp. Sig. 2-tailed) can provide a hypothesis decision on data testing. Validation is done by comparing actual data with data on the alleged presence of mud crabs. The validation value of the existence of mud crab was determined with the formula below (Ghazali 2009):

$$
\mathrm{V}=\frac{\mathrm{n}}{\mathrm{N}} \times 100 \%
$$

Where: V: actual percentage (validation); $\mathrm{n}$ : the number of match points between the actual data and the estimated data; $\mathrm{N}$ : the total number of validation points for the presence of mud crab.

\section{Potential economic value of mangrove crabs}

To find out the calculation of the economic potential value of mud crabs, each mud crab found in the measurement plot was weighed to determine the weight and category (Figure 2), because the weight and category of mud crabs determine the price at which the fishermen will sell them to the nearest agent (Basyuni et al. 2020). In Lubuk Kertang village, there are six categories of mangrove crabs that are commonly traded: pete (weight 30$50 \mathrm{gr}$, price IDR $18000 / \mathrm{kg}$ for nursery purposes), ceka/ashoka crab category (weight $80-100$ gr, price IDR $35000 / \mathrm{kg}$ for sales purposes until the shell becomes hard), category A1 (weight 100-350 gr, price IDR 65000/kg), category AA (weight 350-500 gr, price IDR 80000/kg), category A Super (weight 500-1000 gr, price IDR $115000 / \mathrm{kg}$ ), and female crabs laying eggs (weight $250 \mathrm{gr}$, price IDR 90000-150000). The economic potential value of mud crabs was calculated using the following formula (Cahyadinata et al. 2019):

$$
\text { PNEKB }=\frac{\text { KKB } * \text { LHN } * \text { HIKB }}{\text { BK }}
$$

Where: PNEKB: potential economic value of mud crab (IDR); KKB: density of mud crab (individual/Ha); LHM: extensive mangrove forest (Ha); $\mathrm{BK}$ : weight of mud crab (individual $/ \mathrm{kg}$ ); HJKB: market price of mud crab (IDR $/ \mathrm{kg}$ ).

\section{RESULTS AND DISCUSSION}

In the study area, with 71 measuring plots made, two species of mud crabs were found, namely green mangrove crabs (S. serrata) and red mud crabs (S. olivacea). As many as 57 plots showed the presence of mud crabs caught in crab installation. The remaining 14 plots did not show the presence of mud crabs.

\section{Mud crabs and measured abiotic and biotic factors}

Mud crabs and measured abiotic and biotic factors crabs belonging to the species $S$. serrata and $S$. olivacea were collected. Mud crabs were 120 in number, found in 57 plots; no crabs were detected in 14 plots. The number of crabs found per plot ranged from 0 to 5 (maximum number of crabs found per plot), with a mean number of 2.1. Mud crabs of the species $S$. serrata was found to be 84 in number, with crab density 0.0473 individual $/ \mathrm{m}^{2}$ or 478.6 individual/ha. Meanwhile, S. olivacea mud crabs were 36 in number, with crab density 0.0205 individual $/ \mathrm{m}^{2}$ or 205.13 individual/ha. This finding showed lower density compared to the study of Ulfa (2017), on the rehabilitated mangrove areas in Langsa, Aceh, where it was 3.35-3.65 individual $/ \mathrm{m}^{2}$ and 1.48 individual $/ \mathrm{m}^{2}$ on degraded mangrove areas.

Table 1 summarises the measured abiotic and biotic factors. The environment of mangrove forests indicates a natural-resource environment that is suitable for mud crabs. The development of mud crab aquasilviculture was done by analyzing each observation plot. Data were collected from 71 plots (pertaining to temperature, $\mathrm{pH}$, salinity, dissolved oxygen, mud depth, a distance of the river plot point, the number of potential burrows). 

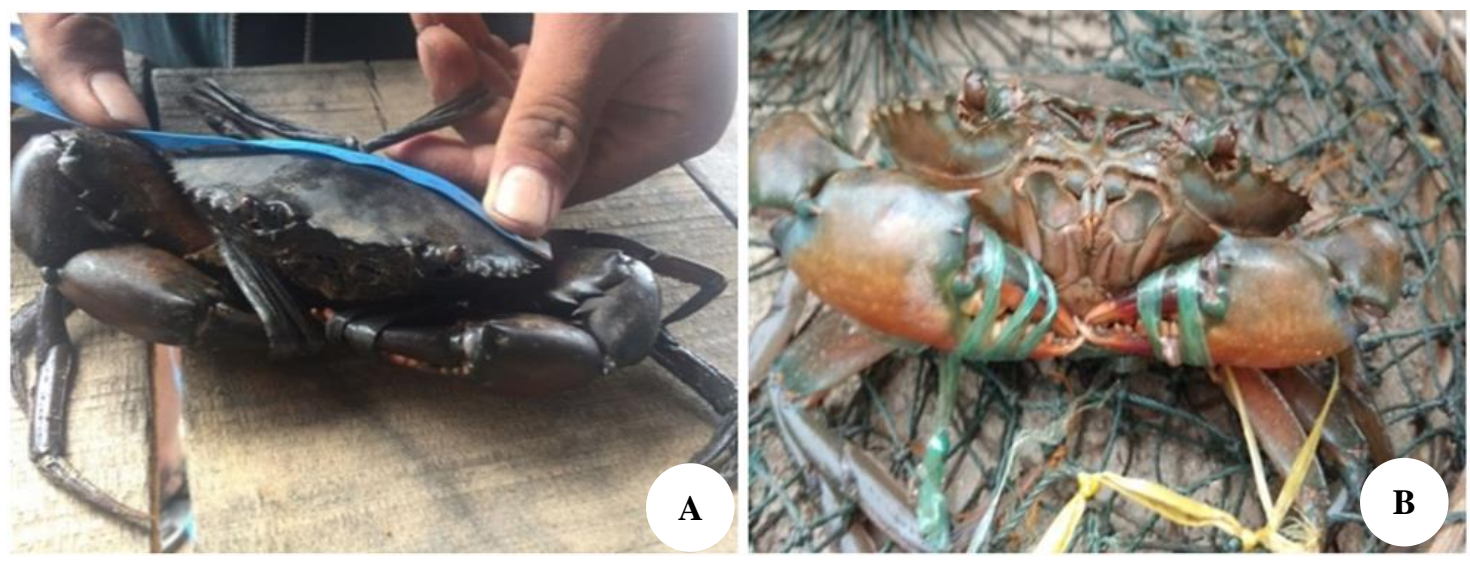

Figure 2. A. Green mud crab (Scylla serrata); B. red mud crab (Scylla olivacea)

Table 1. Minimum value (Min), maximum value (Max), mean and standard deviation of the measured abiotic and biotic factors

\begin{tabular}{lcccc}
\hline \multicolumn{1}{c}{ Parameter } & Min & Max & Mean & Std. Deviation \\
\hline Temperature $\left({ }^{\circ} \mathrm{C}\right)$ & 26.50 & 34.57 & 30.18 & 1.84 \\
$\mathrm{pH}$ & 6.57 & 7.43 & 6.95 & 0.27 \\
Salinity $(\%)$ & 21.67 & 32.33 & 25.69 & 2.95 \\
Dissolved oxygen $(\mathrm{mg} / \mathrm{l})$ & 4.7 & 8.03 & 6.52 & 1.22 \\
Depth of mud $(\mathrm{cm})$ & 28.33 & 233.67 & 121.85 & 52.29 \\
Distance from the river $(\mathrm{m})$ & 0.00 & 215.60 & 215.6 & 27.92 \\
Canopy Cover $(\%)$ & 6.4 & 93.70 & 64.10 & 51.51 \\
Potential burrows & 0.00 & 5.00 & 1.65 & 1.29 \\
\hline
\end{tabular}

$p H$

The lowest $\mathrm{pH}$ was 6.57 and the highest was 7.43 , with an average value of 6.99. The optimal $\mathrm{pH}$ for $\mathrm{crab}$ growth ranges from 7 to 9 (FAO 2011; Hastuti et al. 2019b). Thus, the $\mathrm{pH}$ range recorded at the research location can be considered suitable for mud crabs. Very alkaline or very acidic $\mathrm{pH}$ conditions would be dangerous for these crabs' survival because they would cause metabolic disorders and respiration problems.

\section{Temperature}

The lowest recorded temperature was $26.50{ }^{\circ} \mathrm{C}$ and the highest temperature was $34.57^{\circ} \mathrm{C}$, with an average of 30.05 ${ }^{\circ} \mathrm{C}$. The measured temperature range can be considered a good range for the growth of mud crabs, since, according to Hastuti et al. (2019b), the suitable temperature for the growth of mud crabs is $25-35^{\circ} \mathrm{C}$. If the temperature increases too much, higher evaporation rates will dry the mud substrate. This circumstance makes it difficult for the mud crabs to mate and molt, eventually leading to their death. For instance, this can occur in areas with a large number of human activities that use ships as a means of transportation, or in areas where the natural ecosystems are converted to ship harbors (the substrate becomes artificial and heats up more easily).

\section{Salinity}

The lowest recorded salinity was $21.67 \%$ and the highest was $32.33 \%$, with an average of $25.30 \%$. According to Hastuti et al. (2019b) and FAO (2011), a good salinity range for mud crabs' growth is $21-25 \mathrm{ppt}$ and 25-35 ppt, respectively. Thus, the salinity range measured at the research location is suitable for mud crabs. In a previous study on three species of mud crabs, Scylla serrata was found to be able to tolerate a wide salinity range (Parado-Estepa and Quinitio 2011).

\section{Dissolved oxygen (DO)}

The lowest measured DO was $4.7 \mathrm{mg} / \mathrm{L}$ and the highest was $8.03 \mathrm{mg} / \mathrm{L}$, with an average value of $6.52 \mathrm{mg} / \mathrm{L}$. According to Hastuti et al. (2019b), mud crabs can grow well with a DO range of $6-6,8 \mathrm{mg} / \mathrm{L}$. According to FAO (2011), DO values higher than $5 \mathrm{mg} / \mathrm{L}$ are needed for the growth of mud crabs. DO in the water supports the breathing processes of the biota that lives in it. If the DO is too high (supersaturation), it can have negative consequences for the organisms, such as gas bubble disease in certain fish.

Therefore, the DO should be neither too low nor too high. Oxygen consumption is one of the factors affecting the mud crab juveniles. The amount of oxygen consumed by mud crab juveniles represents a measure of its metabolic rate and it can be used to study the effect of environmental conditions on mud crab juveniles' metabolism (Ikhwanuddin et al. 2015). Growth and survival rate of mud crabs are greatly affected by water temperature which is closely related to concentration of DO in water (Hastuti et al. 2019a), optimum salinity (Ruscoe et al. 2004), season, maturity, and food availability (Siahainenia et al. 2016; Li et al. 2007). 


\section{Mud depth}

The lowest measured mud depth was $28.33 \mathrm{~cm}$ and the highest was $233.67 \mathrm{~cm}$, with an average of $121.85 \mathrm{~cm}$. Since mud crab density is significantly correlated with burrow density (Ulfa 2017), an area with a mud substrate with a good level of inundation, and a sufficient number of natural foods, is a preferred habitat for mangrove crabs. Burrows can be up to $2 \mathrm{~m}$ long and are used as a general shelter by both adult and juvenile mud crabs, especially when they are in the delicate soft-skin stage of the molt cycle and during mating (Morrisey et al. 1999).

\section{Distance from the river}

Mud crabs live better if they are close to rivers and well-preserved mangrove forests (Numbere 2018). The crabs eat mangrove leaves, thereby contributing to litter fall, which help to enrich the mangrove soil which can increase oxygen availability (Bir et al. 2020). Adult mud crabs can survive in salinity as low as 10 ppt (Hastuti 2019b), whereas small crabs have been found in estuaries, tidal plains, and mangroves where they live in mud or sand, and other shaded areas during the day (Quinitio et al 2017); burrowing mud crabs display different movement patterns from those of crabs living in subtidal creeks. Smaller crabs (100-149 mm CW) are hardly found in burrows and inhabit subtidal waters only at low tide and move into the intertidal zone at high tide with peak abundances from spring to autumn (Hubatsch et al. 2015)

\section{Stand density (canopy cover)}

The lowest measured stand density (measured as canopy cover) was $6.4 \%$ and the highest was $93.7 \%$, with an average of $64.10 \%$. Stand density affects the presence of crabs because it is directly proportional to the number of leaves that are produced and fall on the forest floor. Mud crabs act as litter shredder and breaker, decreasing the size of the litter that becomes available to microbial organisms. Microbial communities carry out advanced decomposition functions to produce organic matter and nutrients in the ecosystem. This relationship maintains the ecosystem balance. In addition, it also ensures the sustainability of the food chain and energy flow in the mangrove ecosystem. Mud crabs prefer mangrove trees that have thick, dense roots and grow on soft substrates (Unthari et al. 2018). The availability of shaded areas is considered a very important factor for the survival and growth of mud crabs both in the wild and in aquaculture ponds (Mirera and Moksnes 2014).

\section{Potential burrows}

The lowest number of potential burrows was 0 and the highest was 5 , with an average number of 2 . Potential burrows are used by mud crabs to immerse and defend themselves, to stay cool during low tide, protecting themselves from predators and extreme environmental conditions (Agusto et al. 2020). The mothers of the mud crabs go to the sea or coastal areas with high salinity and release the eggs; therefore, they do not gather and raise the young. The life cycle of mud crabs has been described by Hubatsch et al. (2015). In contrast to sesarmid and fiddler crabs, the potential burrow is also used by the mother to gather and raise her young; they can also use them for food storage, usually in the form of leaf litter and propagules (Andreetta et al. 2014). Ulfa (2017) reported that crab density was significantly correlated with burrow density and significantly higher in the two rehabilitation locations. Some mud crabs were also detected in intertidal areas where low tide burrows are occasionally occupied. Female crabs would rather be buried in the mud than seek shelter in burrows; therefore, the majority of crabs occurred in burrows were males (Hubatsch et al. 2015).

\section{Multicollinearity test}

The results of the multicollinearity test (Table 2) showed that the tolerance value of each independent variable was $>0.10$, which means that there is no correlation between the independent variables. The VIF value of each independent variable was $<10.00$, which means that there is no correlation between the independent variables. The multicollinearity test showed that the considered variables are not correlated; therefore, they can be used in the stepwise logistic regression analysis to investigate which of these variables explain the existence of mud crabs in the study area.

\section{Factors that influence the existence of mud crabs, using binary stepwise logistic regression}

The results of testing the feasibility of the model using the Hosmer and Lemeshow test depicted a chi-square value of 0.00 with a probability value of 1.00 (> 0.05). The model was feasible (accept $\mathrm{H}_{0}$ ) which is the resulting model to explain the data. Therefore, the existing model of mud crab was feasible.

Table 2. Multicollinearity test for the considered independent variables

\begin{tabular}{lcc}
\hline \multicolumn{1}{c}{ Model } & Tolerance & VIF \\
\hline Temperature & 0,57 & 1,72 \\
pH & 0,78 & 1,26 \\
Salinity & 0,73 & 1,35 \\
Dissolved oxysigen & 0,53 & 1,86 \\
Depth of mud & 0,71 & 1,40 \\
Distance from river & 0,95 & 1,04 \\
Canopy cover & 0,75 & 1,31 \\
\hline VIF: variance inflation factors
\end{tabular}

VIF: variance inflation factors

Table 3. Partial test and model formation

\begin{tabular}{lccccccc}
\hline \multicolumn{1}{c}{ Predictor } & B & S.E. & Wald & Df & Sig. & Exp(B) \\
\hline Constant & $-6607,51$ & 110053,56 & 0.004 & 1 & 0,95 & 0,00 \\
Dissolved oxysigen & 983,89 & 16399,21 & 0.004 & 1 & 0,95 &. \\
Depth of mud & 6,78 & 112,47 & 0.004 & 1 & 0,95 & 882.21 \\
\hline
\end{tabular}

B: beta coefficient, SE: standard error, $\operatorname{Exp}(B)$ : odds ratio, Df: degree of freedom 
Based on Table 3, the stepwise logistic regression analysis selected the dissolved oxygen and mud thickness as the best predictors (independent variables) for the presence of mud crabs in the study area. The probability of the presence of mud crab in areas that have high dissolved oxygen and high mud thickness will be predicted by the model as an area with a high probability of mangrove crab presence. Areas with low dissolved oxygen and low mud depths will be predicted by the model as areas with a low probability of mud crab presence.

The dissolved oxygen and the depth of the mud are directly proportional to the chance of the presence of mangrove crabs, which indicates the presence of more mangrove crabs. The chances of the presence of mud crab in areas that have high dissolved oxygen and high mud thickness will be predicted by the model as an area with a high chance of the presence of mangrove crabs.

The presence of mud crabs is directly related to the thickness of the mud, indicating that the presence of mangrove crabs is more in areas that have a high mud depth. This happens because the higher the depth of the mud, the more is the opportunity for the mud crabs to mate and molt.

Dumas et al. (2012) found that the stand density contributed significantly to the mud crab density. This study used generalized linear models (GLM) and obtained a significance of $84.80 \%$. Regression analysis showed the magnitude of the correlation between crab density and burrow density $(\mathrm{p}<0.01)$. Besides, the density of the burrow was seen to be significantly greater $(\mathrm{p}<0.05)$ than the density of the crab.

In general, the writing models for estimating the existence of mud crab based on Table 2 are formed as follows:

$$
\mathrm{Y}=\frac{\operatorname{Exp}\left(-6607,51+983,89 \mathrm{X}_{1}+6,78 \mathrm{X}_{\mathrm{V}}\right)}{1+\operatorname{Exp}\left(-660751+983,89 \mathrm{X}_{1}+6,78 \mathrm{X}_{2}\right)}
$$

Where: Y: opportunities for crab existence; $\mathrm{X}_{1}$ : dissolved oxygen $(\mathrm{mg} / \mathrm{L}) ; \mathrm{X}_{2}$ : mud depth $(\mathrm{cm})$.

Variables that influence the presence of mud crab are dissolved oxygen and mud thickness. The dissolved oxygen variable of beta coefficient (983.89) indicates that dissolved oxygen has a positive effect on the chances of the presence of mangrove crabs. The mud thickness variable of 6.78 indicates that depth of mud has a positive effect on the chance of the presence of mangrove crabs. The presence of mud crab is influenced by the dissolved oxygen factor and the depth of the mud as much as $68.70 \%$. In other words, the contribution of the dissolved oxygen and the depth of the mud to the presence of the mud crab is $68.70 \%$, while the remaining $31.30 \%$ is contributed by other variables which were not measured in this study. The growth of mud crabs is supported by water temperature because mud crabs are poikilotherms. Temperature will affect activity, appetite, oxygen consumption, and metabolic rate of mud crabs (Hastuti et al. 2019b).

The existence of mangrove crabs is influenced by the good management of mangrove areas as a breeding ground for mangrove crabs (Dayal et al. 2019). Mangrove areas that are well managed can provide good growth for the mangrove trees in the area. Mangrove trees that grow well will have a dense crown and a large diameter. The size of the crown is directly proportional to the number of leaves (Unthari et al. 2018). The dense canopy has many leaves, so that more and more litter falls on the forest floor. The litter that falls on the forest floor is one of the natural foods for mangrove crabs. Dumas et al. (2012) stated that mangrove crabs are typically associated with good mangrove ecosystems, so that better the management of the mangrove area, the more the number of mangrove crabs living in the area will increase. Based on observations of body shape, mangrove crabs have enough food, but a lot of energy is used for growth. The condition index reflects the interaction between biotic and abiotic factors that influence physiological processes in fish (Rahman et al. 2012). According to Fatihah et al. (2017), the carapace-length growth rate of mangrove crabs is determined by natural activities such as the molting process.

\section{Validation of opportunities for the existence of mud crabs}

The results of data validation testing using the Wilcoxon Test Statistics test is displayed in Table 4. Based on Table 4, information is obtained that the Z-value was 1.73 with a p-value (Asymp. Sig 2 tailed) of 0.08 , where more than the critical limit of research $(>0.50)$ is categorized as mud crab in the area; therefore, the hypothesis decision is to accept $\mathrm{H} 0$. This result shows that there is no real difference between the actual data and the alleged data. The validation value of the model was $90 \%$, which means that $90 \%$ of the data between the actual data and the alleged data were the same.

\section{Potential economic value of mud crabs}

Mud crabs are an economically important crustacean species for fisheries and aquaculture (Shi et al. 2019). Based on research data from various locations (Williams and Primavera 2001; Fazhan et al. 2020), two types of mangrove crabs were found, namely green ( $S$. olivacea) and red mud crab (S. serrata), with six categories based on specific weights, namely banana crab, ceka crab, category A1, AA, A super, and female crab laying eggs. Mangrove crabs that are commonly found in the mangrove forest areas of the research location were the banana, ceka, and A1 categories. Based on observations of body shape, mud crabs have enough food, but a lot of energy is used for growth. The condition index reflects the interaction between biotic and abiotic factors that influence physiological processes in fish (Rahman et al. 2012). According to Fatihah et al. (2017), the growth rate of carapace length of mangrove crabs is determined by natural activities such as the molting process (Basyuni et al. 2020).

Table 4. Wilcoxon test statistics

Actual-estimate

$\begin{array}{lc}\text { Z } & -1,73 \\ \text { Asymp. Sig (2-tailed) } & 0,08\end{array}$


Fishermen that work as mud crab catchers (Scylla sp.) sell their catches to the nearest agent. Each commercial category is sold at a different price: banana category (weight: $30-50 \mathrm{~g}$, price: IDR $18000 / \mathrm{kg}$, for nursery purposes), ceka/Ashoka crab category (weight: 80-100 g, price: IDR $35000 / \mathrm{kg}$, for sale purposes until the shell becomes hard), A1 category (weight: 100-350 gr, price: IDR $65000 / \mathrm{kg}$ ), AA category (weight: $350-500$ gr, price: IDR $80000 / \mathrm{kg}$ ), category A Super (weight: 500-1000 gr, price: IDR $115000 / \mathrm{kg}$ ), and female crabs laying eggs (weight: 250 gr, IDR 90000-150000).

The estimated economic potential of mud crabs $(S$. serrata and $S$. olivaxea) in the Lubuk Kertang Mangrove Forest (Lubuk Kertang Village) was IDR 2,392,000.00/ha. Fishermen and crab aquaculture owners recommend that the government pay attention to this sector to prevent overexploitation of these species and environmental damage affecting their habitats. Fishermen are becoming increasingly interested in farming mud crabs (Basyuni et al. 2020; Bir et al. 2020).

In conclusion, mangrove forests in the village of Lubuk Kertang are a suitable place for the development of mud crabs. The most influential parameters, as observed in this study, were dissolved oxygen and mud depth. Because the mud crabs are a significant fishery resource in this area, it is important to preserve the local mangrove forests and ensure that the ecosystems hosting these crabs are not destroyed by human activities.

\section{ACKNOWLEDGEMENTS}

This study was supported by a Research Grant from The Indonesian Science Fund and Indonesia Endowment Fund for Education (DIPI/LPDP-RCUK Joint Call) (Grant Number N0. NE/PO14127.1)

\section{REFERENCES}

Agusto LE, Fratini S, Jimenez PJ, Quadros A, Cannicci S. 2020 Structural characteristics of crab burrows in Hong Kong mangrove forests and their role in ecosystem engineering. Estuar Coast Shelf Sci 106973. DOI: 10.1016/j.ecss.2020.106973.

Andreetta A, Fusi M, Cameldi I, Cim` F, Carnicelli S, Cannicci S. 2014. Mangrove carbon sink. Do burrowing crabs contribute to sediment carbon storage? Evidence from a Kenyan mangrove system. J Sea Res 85: 524-533. DOI: 10.1016/j.seares.2013.08.010

Anju A, Smitha CK, Preetha K, Boobal R, Rosamma P. 2019. Molecular characterization, recombinant expression and bioactivity profile of an antimicrobial peptide, Ss-arasin from the Indian mud crab, Scylla serrata. Fish Shellfish Immunol 88: 352-358. DOI: 10.1016/j.fsi.2019.03.007.

Archer K.J, Lemeshow S, Hosmer DW. 2007. Goodness-of-fit tests for logistic regression models when data are collected using a complex sampling design. Comput Stat Data An 51: 4450-4464. DOI: 10.1016/j.csda.2006.07.006.

Azra MN, Ikhwanuddin M. 2016. A review of maturation diets for mud crab genus Scylla broodstock: Present research, problems and future perspective. Saudi J Biol Sci 23 (2): 257-267. DOI: 10.1016/j.sjbs.2015.03.011

Basyuni M, Indrawan R, Putri LAP, Yusraini E, Lesmana I. 2020. Molting mud crab (Scylla serrata) in the mangrove ecosystem service. IOP Conf Ser Earth Environ Sci 454: 012125. DOI: 10.1088/1755$1315 / 454 / 1 / 012125$
Basyuni M, Gultom K, Fitri A, Susetya IE, Wati R, Slamet B, Sulistiyono N, Balke T, Bunting P. 2018. Diversity and habitat characteristics of macrozoobenthos in the mangrove forest of Lubuk Kertang Village, North Sumatra. Biodiversitas 19 (1): 311-317. DOI: 10.13057/biodiv/d190142.

Bir J, Islam SS, Sabbir W, Islam MR, Huq KA. 2020. Ecology and reproductive biology of Mud Crab (Scylla spp): A study of commercial mud crab in Bangladesh. Int J Acad Rese Dev 5 (2): 1-7.

Cahyadinata I, Fahrudin A, Sulistiono, Kurnia R. 2019. Household welfare of mud crab fishermen in small outermost islands. Case study: Enggano Island, Bengkulu Province, Indonesia. AACL Bioflux 12 (2): 564-574

Dan S, Hamasaki K. 2014. Evaluation of the effects of probiotics in controlling bacterial necrosis symptoms in larvae of the mud crab (Scylla serrata) during mass seed production. Aquac Int 23 (1): 277 296. DOI: 10.1007/s10499-014-9815-1.

Dayal JS, Balasubramanian CP, Ambasankar K, Jannathulla R, Claret EA. 2019. Effect of dietary protein level on fattening and mineral profiles of mud crab (Scylla serrata) in individual cages under mangrove ecosystem. Aquac Res 50 (7): 1993-2003. DOI: 10.1111/are.14094

Dumas P, Léopold M, Frotté L, Peignon C. 2012. Mud crab ecology encourages site-specific approaches to fishery management. J Sea Res 67 (1): 1-9. DOI: 10.1016/j.seares.2011.08.003

Fatihah SN, Julin HT, Chen CA. 2017. Survival growth and molting frequency of mud crab (Scylla tranquebarica) juveniles at different shelter conditions. AACL Bioflux 10 (6): 1581-1589.

Fazhan H, Waiho K, Quinitio E, Baylon JC, Fujaya Y, Rukminasari N, Azri MFD, Shahreza MS, Ma H, Ikhwanuddin, M. 2020. Morphological descriptions and morphometric discriminant function analysis reveal an additional four groups of Scylla spp. PeerJ 8: e8066. DOI: 10.7717/peerj.8066.

Fitri A, Basyuni M, Wati R, Sulistiyono N, Slamet B, Harahap ZA, Balke T, Bunting P. 2018. Management of mangrove ecosystems for increasing fisheries production in Lubuk Kertang village, North Sumatra, Indonesia. AACL Bioflux 11 (4): 1252-1264.

Fawwaz M, Vemilia P, Mutmainnah I, Baits M. 2019. Scylla serrata Forskal as natural source of glucosamine hydrochloride. J Res Pharm 23 (2): 259-266. DOI: 10.12991/jrp.2019.132.

Food and Agriculture Organization (FAO). 2011. Modul Mud Crab Culture. FAO, Rome.

Ghazali I. 2009. Aplikasi analisis multivariate dengan program SPSS, cetakan ke IV. Badan Penerbit UNDIP, Semarang. [Indonesian]

Glaser M, Diele K. 2004. Asymmetric outcomes: Assessing central aspects of the biological, economic and social sustainability of a mangrove crab fishery, Ucidescordatus (Ocypodidae), in North Brazil. Ecol Econom 49 (3): 361-373. DOI: 10.1016/j.ecolecon.2004.01.017.

Hastuti YP, Nirmala K, Suryani I, Prasetiyo SL. 2019a. Environmental characteristics of mangrove forest as a reference for development of mud Crab (Scylla serrata) cultivation: A case study in Mojo Village, Ulujami, Pemalang. IOP Conf Ser Earth Environ Sci 278: 012035. DOI: 10.1088/1755-1315/278/1/012035.

Hastuti YP, Affandi R, Millaty R, Nurussalam W, Tridesianti S. 2019b. The best temperature assessment to enhance growth and survival of mud crab (Scylla serrata) in recirculating system. Jurnal Ilmu dan Teknologi Kelautan Tropis 11 (2): 311-322. DOI: 10.29244/jitkt.v11i2.22727. [Indonesian]

Hosmer JDW, Lemeshow S, Sturdivant RX. 2013. Applied Logistic Regression (Vol. 398). John Wiley \& Sons.

Hubatsch AH, Lee SY, Meynecke JO, Diele K, Nordhaus I, Wolff M. 2015. Life-history, movement, and habitat use of Scylla serrata (Decapoda, Portunidae): Current knowledge and future challenges. Hydrobiol 763 (1): 5-21. DOI: 10.1007/s10750-015-2393-z.

Hungria DB, dos Santos Tavares CP, Pereira LÂ, da Silva U, Ostrensky, A. 2017. Global status of production and commercialization of softshell crabs. Aquac Int 25(6): 2213-2226. DOI: 10.1007/s10499-0170183-5

Ikhwanuddin M, LanSS, Hamid AN, Zakaria FSN, Azra MN, Aisah SA, Munafi AB. 2015. The embryonic development of orange mud crab (Scylla olivacea) (Herbst, 1796) held in the captivity. Iran J Fish Sci 14 (4): 885-895.

Indarjo A, Salim G, Zein M, Septian D, Bija S. 2020. The population and mortality characteristics of mangrove crab (Scylla serrata) in the mangrove ecosystem of Tarakan City, Indonesia. Biodiversitas 21 (8): 3856-3866. DOI: 10.13057/biodiv/d2 10855 
Li L, Chen C, Zeng X, Chen Nyu, Lai Q, Qin JG. 2007. Growth, body composition, respiration and ambient ammonia nitrogen tolerance of the juvenile white shrimp Litopenaeus vannamei at different salinities. Aquaculture 265: 385-390. DOI 10.1016/j.aquaculture.2007.02.018.

Lee SY. 1998. Ecological role of grapsid crabs in mangrove ecosystems: A review. Mar Freshw Res 49 (4): 335-343. DOI: 10.1071/MF97179.

Mirera DO, Moksnes PO. 2014. Comparative performance of wild juvenile mud crab (Scylla serrata) in different culture systems in East Africa: Effect of shelter, crab size and stocking density. Aquac Int 23 (1): 155-173. DOI: 10.1007/s10499-014-9805-3.

Morrisey DJ, DeWitt TH, Roper DS, Williamson RB. 1999. Variation in the depth and morphology of burrows of the mud crab Helice crassa among different types of intertidal sediment in New Zealand. Mar Ecol Prog Ser 182: 231-242.

Murdiyarso D, Purbopuspito J, Kauffman JB, Warren M., Sasmito SD, Donato DC., Manuri S, Krisnawati H, Taberima S,. Kurnianto S. 2015. The potential of Indonesian mangrove forests for global climate change mitigation. Nat Clim Change 5 (12): 1089-1092.DOI: 10.1038/nclimate2734.

Numbere AO. 2018. Mangrove Species Distribution and Composition, Adaptive Strategies and Ecosystem Services in the Niger River Delta Nigeria. Mangrove Ecosystem Ecology and Function, Intechopen, United Kingdom

Parado-Estepa FD, Quinitio ET. 2011. Influence of salinity on survival and molting in early stages of three species of Scylla crabs. Isr J Aquacult-Bamid 63 (6): 1-6.

Petersen EH, Phuong TH, Van Dung N, Giang PT, Dat NK, Tuan VA, Nghi TV, Glencross BD. 2013. Bioeconomics of mud crab, Scylla paramamosain, culture in Vietnam. Rev Aquac 5 (1): 1-9. DOI 10.1111/j.1753-5131.2012.01073.x.

Quinitio ET, Huervana JJ, Estepa FDP. 2017. Quality assessment of newly hatched mud crab, (Scylla serrata), larvae. Aquac Res 49 (1): 75-80. DOI: 10.1111/are.13434.

Rahman K, Khan A, Muhammad NM, Jo J, Choi KH. 2012. Fineresolution patterning of copper nanoparticles through electrohydrodynamic jet printing. J Micromech Microeng 22 (6) 65012. DOI: 10.1088/0960-1317/22/6/065012.
Ruscoe IM, Shelley CC, Williams GR. 2004. The combined effects of temperature and salinity on growth and survival of juvenile mud crabs (Scylla serrata Forskål). Aquac 238 (1-4): 239-247. DOI: 10.1016/j.aquaculture.2004.05.030.

Salim G, Rachmawani D, Septian D. 2018. Analisis model sifat pertumbuhan dan indeks kondisi kepiting bakau (Scylla serrata) yang berasal dari perairan estuaria Kota Tarakan. Jurnal Borneo Saintek 1 (3): 1-12. DOI: 10.35334/borneo_saintek.v1i3.929. [Indonesian].

Shi X, Lu J, Wu Q, Waiho K, Aweya JJ, Fazhan H, Zhang Y, Li S, Zheng H, Lin F, You C, Ikhwanuddin M, Ma H. 2019. Comparative analysis of growth performance between female and male mud crab (Scylla paramamosain) crablets: Evidences from a four-month successive growth experiment. Aquac 505: 351-362. DOI: 10.1016/j.aquaculture.2019.02.062

Siahainenia L, Natan Y, Khouw AS, Pattikawa JA. 2016. Size distribution, growth pattern and condition factor of mangrove crab (Scylla serrata) in the coastal waters of Western Seram, Maluku, Indonesia. Int J Fish Aquat Stud 4 (2): 291-296.

Tetelepta JMS, Natan Y, Pattikawa 1JA, Ongkers OTS, Pattiasina BJ. 2019. Fishery of mud crab (Scylla serrata) of Kotania Bay, Western Seram District: Potency, stock status and sustainable management. IOP Conf Ser Earth Environ Sci 339: 012002. DOI: 10.1088/1755$1315 / 339 / 1 / 012002$

Ulfa M. 2017. The Role of Mangrove Rehabilitation on Density and Distribution Patterns of Mangrove Crabs (Scylla sp.) in Kuala Langsa, Aceh. [Thesis]. Gajah Mada University, Yogyakarta. [Indonesian]

Unthari DTAI, Purwiyanto, Agussalim A. 2018. Relationship between mangrove density against the abundance of mangrove crab (Scylla sp.) with the use of bubu lipat as a fishing gear in the Bungin River Banyuasin Regency, South Sumatra Province. Maspari 10 (1): 41-50.

Williams MJ, Primavera JH. 2001. Choosing tropical portunid species for culture, domestication and stock enhancement in the Indo-Pacific. Asian Fish Sci 14 (2): 121-142.

Wilson KA. 1989. Ecology of mangrove crabs: Predation, physical factors and refuges. Bull Mar Sci 44 (1): 263-273.

Yoo W, Mayberry R, Bae S, Singh K, He QP, Lillard Jr JW. 2014. A study of effects of multicollinearity in the multivariable analysis. Int $\mathbf{J}$ Appl Sci Technol 4 (5): 9-19. 